\title{
Brazil's grand border strategy: challenges of a new critical thinking in a modern era
}

\section{Estratégia Fronteiriça Brasileira: desafios de um novo pensamento crítico em uma era moderna}

\section{MIGUEL DHENIN PAULO GUSTAVO PELLEGRINO CORREA}

\section{INTRODUCTION}

This paper is part of a larger study, a Ph.D. thesis in political science and geography. Among the different issues that we intend to analyze during the course of the program, borderlands and security studies are central to our study. The Brazilian's grand border strategy is a concept that had different paths and interpretations during the Republican era. Therein, we provide an analysis of the characteristics of this grand strat$e g y$, and we quickly offer an overview of the influential role military elite in the domestic affairs.

First, the political influence of the military, in the early decades of the $20^{\text {th }}$ century, on Brazil's intern affairs, had an important effect on the organization of the State and society. Perhaps the Vargas era, during the 'New State' coup of 1937 really designed the pattern of presence of military forces in domestic affairs. World War II also provided the military with a big influence, in a moment of Brazilian history that rise the open democracy as a new model. However, the military elite who fought in the Brazilian Expeditionary Force (or Força Expedicionária Brasileira) return

\footnotetext{
Miguel Dhenin - Universidade Federal do Amapá. PhD in Political Science. Temporary Professor of the International Relations Undergraduate Program of the Federal University of Amapá - UNIFAP. Paulo Gustavo Pellegrino Correa - Universidade Federal do Amapá. PhD in Political Science. Professor of the International Relations Undergraduate Program of the Federal University of Amapá - UNIFAP and of the Postgraduate Program in Border Studies of UNIFAP (PPGEF) and of the Postgraduate Program in Development of the Amazon of the Federal University of Roraima (PPGDRA). This researcher received support from the Pro-Defense (Call 031-2013). Researcher of the Guiana Shield Frontier Observatory - OBFRON.
} 
home with the ideas and concepts of the US War College. One of the most important of it was the National Security Doctrine, promoted during the McCarthy period in the United States. For the Brazilian military, the internal enemy, also known as 'communism' represent the main threat regarding its domestic security (Oliveira, 1976).

The creation of the Brazilian War College (or Escola Superior de Guerra) was the expression of a need of elites to theorize the issues and prepare a 'revolution' in order to protect the country from the eminent threat. After long years of internal crisis during the 1960's, the coup (both civil and military) of 1964, that took place in March $31^{\text {th }}$, marked the moment that the military elite finally assumed its political responsibility (Dreifuss; Dulci, 2008). The head of the coup was not prepared to have this role and started to gain the total control of the executive and legislative branch (through the Institutional Act laws, bypassing the Congress and putting a dictatorial regime in place until 1985. The unprecedented moment for Brazilian military launched a series of projects, mainly in the development domain. For them, security and development were link and the conquest and vivification of the Amazon region and its uninhabited borders was a matter of national security (Stepan, 1971).

This paper will offer a panorama of the Brazilian military thinking towards the strategic issue of boundaries, from the return to democracy (or during the democratic transition) until the most recent moments. The first part of the work in a presentation of the Security and Development Doctrine, that influenced the regime in order to solve the presence dilemma in the Amazon region. Then, we point out that despite the changes in the political order, the border strategy of Brazil remains the same, and the elite kept the same concepts that were used. Finally, we offer a proposal that distance itself from the previous interpretation of the military presence in the remote areas, stressing the importance of locals and de-securitizing the border issues.

\section{NATIONAL SECURITY DOCTRINE PUT IN PRACTICE: THE CASE OF AMAZONIA (1950-1980)}

During the conquest of the Amazonia, the Portuguese faced many challenges. The logistic component surely represented a very decisive element for the bandeirantes. Rough conditions of the landscape and the rain forest, for most of its parts, forced the military armed forces to build a series of strongholds, near the rivers, mostly in strategic areas (Gadelha, 2002). This presence had also a civilizational purpose, and the military quickly understood the necessity of creating a good relationship with natives. 
During the $19^{\text {th }}$ century, in parallel of the military forces, another important actor had a role in the region: the missionaries. The Jesuitas were part of an evangelical process that was settle to guarantee the stabilization of the region (Dos Santos, 2010). Through the $20^{\text {th }}$ century, the consolidation of the Republic and the central political place of the military (mainly during the 'Old' Republic) made it easier to develop a specific strategy of presence (Ferreira, 2005). An important political figure, Marshall Cândido Rondon was in charge of putting in place telegraphs lines into the deepest and remote areas of Brazil, that was a state action know as Rondon Comission. At the time (1907-1915) the railroad Madeira-Mamoré was being built, and Amazonia surely did represent an important geopolitical challenge. The mission had also a strategic purpose. Marshall Rondon and Army officers were very close to natives and helped to create a myth and popularized the indigenous people and its incorporation into the Brazilian Army ${ }^{1}$. During the First and Second World War, the Amazon region played an important part, notably because of the important demand of latex from the U.S. and the Allies (Garfield, 2009).

The presence of troops in the Amazon relates to the Brazilian foreign policy during the early $20^{\text {th }}$ century. The head diplomat José Maria da Silva Paranhos Júnior (also known as Barão do Rio Branco) had a tough challenge demarking the Brazilian border with the neighboring countries. Negotiating was often the solution between parts and force was not use as a first solution to solve issues. In some occasions, an independent arbitral commission was necessary in order to rule, as it occurred for the demarcation of French Guiana and Brazil borders (Bueno, 2012). The presence of troops in Amazonia sent a clear message to the other countries that Brazil was preoccupied to defend its sovereignty. During the next decades, regional tensions sparkled but never really affected the South American region. The study of Amazonia offered intellectuals a new outlook regarding the role of this very specific region in Brazil's strategic development. Classic authors, such as Euclides da Cunha, wrote a lot about the difficult conditions that people lived at this time (Ginzburg, 2010). The necessity of state presence was, in fact, a local demand, that was embraced by the Brazilian Armed Forces. Needless to say, in that moment, the Amazonia was a remote region, both in geographic and political terms, and never was a priority for the Southern elites, who ruled the country.

Many policies regarding Amazonia were in place during the $2 \mathrm{O}^{\text {th }}$ century (D'Araújo, 1992). One of these policies was the 'March to the West'. The objective was to densify the presence of population in the central rural zone of Goiás, Mato Grosso and Pará. During this period, federal agencies, such as the Nacional Council of Geography, the National Council of 
Cartography, the National Council of Statistics, and the Brazilian Institute of Statistics and Geography, started to develop their research program, all of them in 1958. The Vargas government, especially during the 'New State' era (the Estado Novo was the authoritarian regime that stood between 1937 until 1945) wanted to build a State within the State, a new society and produce a feeling of nationalism for Brazil. One key dimension was the geopolitics, which had the territory in his scope. It is important to note that the justification for the development of Amazonia by the military regime was in fact the National Security Doctrine. According to José Goldemberg and Eunice R. Durham, this doctrine was 'a byproduct of the Cold War'. It was created by the United States to insure its hegemony in Latin America and adopted by the large sectors of Brazil's armed forces. Geopolitical conceptions in that doctrine characterized all governmental policies during that period, furthering a real militarization of the Amazon question.'

Brazil's Escola Superior de Guerra (the Brazilian War College) began to develop national security doctrines in the 1950's (Stepan, 1973) and the link between national development and security resonated easily with officers already familiar with geopolitical thinking (Mares, 2010). Under the influence of the Sorbonne Group of the Brazilian War College, the settlement of the Amazon under the direction of a technocratic, centralized state machine would serve mutually reinforcing development goals (Hall, 2000). Since then, security, and specifically national security, seems to have a close relationship with Amazonia. We should note here that the geopolitical writings of the Brazilian authoritarian period formed the theoretical foundation of modern Amazonian geopolitics (Hepple, 1986). Therefore, any discourse about the Amazon region, from a political perspective, must include a security perspective. According to Xavier de Sartre:

$[\cdots]$ the second time an internationalist conspiracy was formally denounced occurred in the 1960's and 1970's. This was spearheaded by leading strategists and theoreticians during the authoritarian period in Brazil, who envisaged Amazonian development in their discourse about security: the military's national security concerns for political stability and secure international borders necessitated the settlement of the Amazonian frontier (De Sartre; Taravella, 2009).

During the early 1950s, the Brazilian War College was created in order to build a strategic center able to offer policies and help the national elites. The influence of the geopolitical school was very important for the consolidation of conservative politics.

The Escola Superior de Guerra was founded by former veterans during World War II, who also served during the Italian Campaign in 1943. 
Many of these officers visited the U.S. after the war and were very impressed by the means at disposal to produce a strategic thinking. Everardo Backheuser, the ancestor and the Brazilian geopolitical school were involved in this process (Backheuser, 1952). One of the main figure was Golbery do Couto e Silva, serving as coronel at the time. As an Army officer, he wrote an important number of essays regarding geopolitical concepts and was especially interested by the role of the Amazon region (Silva, 1967). The territorial occupation mapped the Brazilian geopolitics during decades from 1950 to 1980 . During this period, the global political context was the bipolarization of the world and the necessity of a strategic reflection was obvious for the military. The Mackinder concept of 'heartland' was present during all the manifestations of the Brazilian geopolitical school, regarding the Brazilian's state. 'Occupation and vivification' was the motto of the military. Another Army officer, Carlos da Meira Mattos, was also influential in the Brazilian Geopolitical School. His early work dealt about the geopolitical influence of autonomous thinking (De Meira Mattos, 1990).

It is important to highlight the beginning of the more internationalized discussion about the environment and international action for human effects in nature. This is marked by the United Nations Conference on the Human Environment in Sweden in 1972 known as the Stockholm Conference. The occasion started a new international ecopolitics, with a concept that was designed in Brazil by José Eli da Veiga and Edson Passetti and brought to the field of security study the possibility of having the environmental sector as the focus of analysis. In this direction, the systemic discussion on the effects of the man / nature relationship brings National States a challenge in formulating their policies. If on the one hand the effects on the environment are of territorial order that go beyond national borders, on the other hand, the use of nature is found in States that claim sovereignty over the use of their territory. In this new discussion about the environment, the world's largest tropical forest, the Amazon, is now more internationally prominent.

Due to such interest, especially after the the mencioned Conference, the Amazon countries have strengthened their agendas for this region, fearing the discourse of internationalization and narrow sovereignty by developed countries. A supposed campaign of internationalization of the Amazon reverberated with intensity in Brazil. João Roberto Martins Filho points out that in the 1980 s, military and civilians were referring to an international campaign that would threaten Brazilian sovereignty over the Amazon' (Martins Filho Jr., 2003, 271). According to the author, 'it is possible to affirm that the Brazilian military enters the $21^{\text {th }}$ century more 
and more convinced that the threat of foreign intervention by the world powers is the axis of the defense problem of the Amazon' (Martins Filho Jr., 2003, 276). The securitization of the internationalization intentions of the Amazon generated a national reaction from the Amazonian countries, increasing the military contingent in the region, but also building joint actions such as the signing of the Amazon Cooperation Treaty (TCA). To counter the criticism of the Amazon region, eight countries in the region signed the Amazon Cooperation Treaty, on the initiative of the Brazilian government, in July 1978, which dealt, in addition to environmental issues, with sovereignty and possible physical integration of the region, although this last item has been taken from the final version of the document

In 2002, the transformation of the treaty into an organization sought some objectives such as boosting South America's physical and energy integration strategy; to consolidate a regular and constant diplomatic space of relationship with eight of the twelve South American countries; through greater institutionalization, to make this articulation between countries less vulnerable to variations in circumstances and positions, that is, not to depend on the initiative of governments and representatives to schedule meetings, set up guidelines, close agreements, formulate and execute projects, etc. ; strengthening the search for credibility building at the international level, investing in the capital represented by the image of the Amazon (Antiquera, 2008, 151).

A special essay emphasizes the role of Pan-Amazon region offers an interesting reflection on the main issue. Carlos Meira Mattos emphasized the necessity of internal plans: big projects such as the Transamazonian highway, the Andean Community of Nations (CAN), the Superintendence of the Amazon Development (SUDAM) and Polo Amazonia were at the core of the Security and Development doctrine. In other words, the ESG reinforced and consolidated their theories while at the same time disseminating the essence of Brazilian geopolitics to the military-technocratic elites, which give directions and purpose to Brazil's development process and international relations. The National Security Doctrine identified the goals a nation should have and the factors that would determine its success. The doctrine itself required implementation and thus the other two characteristics of the NSS became key to understand the whole process. In order to understand the National Security Doctrine, we must analyze the nomenclature of the so-called 'National Security State' or NSS. According to the classical literature (Kelly; Child, 1988), the fundamentals elements of the NSS were: the professional military only rule for reasons of national security; the defense of national security requires system transformation (Stepan, 1971); economic policy is a mix strategy which the government 
remained a key play in markets deemed important for national development (Evans, 1979); the elite: 'another empirical variation among national security states is their degree of inclusiveness of social groups into their policy-making circles'. Put in a synthetic system, we had:

The ideology of national security

The belief that national security professionals should lead

Perception of intelligence as a key defense mechanism

The study of geopolitics was imported from Europe and it had a great impact in South America.

The National Security ideology recognized that security and development required the institutionalization of a political and economic system, not just arbitrary 'cleansing' and commanding. Military leadership and the new regime, therefore, require legitimacy. They cannot be established simply by force, even if it was the force of an elite. For the application of the doctrine, it was important to develop the permanent national objectives. Said to be stable, long term national goals, which gave specific content to the National Security Doctrine.

The lack of a critical thinking in the process of transformation of Amazonia (1980-2000)

The National Security Doctrine (NSD) founds its origins during the Cold War. President Truman and Foster Dulles had clearly in mind who was the enemy after winning World War II over Germany and Japan. The threat of communism was the main reason that made the U.S. government to start an atomic race and deterrence tension during the 1960's and 1970's. For the U.S., the main danger to national security was explained by endogenous factors (i.e. intern subversion (local communists groups considered by authorities as subversive) or exogenous factors (direct threat from a communist country (i.e. Soviet Russia or Cuba). The influence that Russia had on Third World countries changed the pattern of the NSD. For now on, the counter-revolutionary part of the NSD was very important and was specially destined to poor countries in struggling economies, like in Latin America, because of the damaging images of the Vietnam War. The NSD subtly changes during the 1970 s and the Nixon-Kissinger doctrine was not going to intervene on the ground with troops but rather equipped the Armed Forces of satellite countries, to defend itself from subversions (mainly communism). The warfare was a guerrilla type one (Talbott, 1976).

According to the theories of geopolitics in Brazil, Latin America was interconnected and integrated to the anti-communist block. The main argument was simple for the authors: Brazil had an important role for Western security because of two aspects: a) the safety/defense of the American 
continent that, facing the communist threat, will be the stronghold of the free world and democracies and b) guarantee of the Atlantic safety, because Brazil was located on a strategic area that incite the afro-euro-asian continental mass (Silva, 1967). On the two aspects, Brazil was connected to global western security strategy. When the military took over in 1964, the whole process of capitalist expansion accelerated. Military leaders were obsessed with the possibility of a foreign takeover of the region. They wanted to integrate Amazonia with the rest of Brazil quickly, so the government allied itself with big capital in this endeavor. All sorts of tax incentives were given to businesses to settle in the region along the Belém-Brasília highway. Foreign capital was easily obtained from international lending institutions, such as the World Bank, because the military coup had the approval of the U.S. government, which supported the overthrow of the leftist government of João Goulart (De Sartre; Taravella, 2009). With the comeback of democracy in the late 1980s, Brazil did not change drastically. The transition was a painful moment of Brazilian political history and many head officers were still playing important roles in the new 'democratic' government. The end of Cold War and the broad security agenda (as if environment, human rights and transnational illegals (drugs) were motives of preoccupation for the Brazilian Armed Forces, because of the diminishing visibility whether force could be use (Marques, 2005). The officers presume that conflictive East-West relationships were now between the North and South. Defending the nationalist point of view, the possible interference of international organizations was possibly a threat for Brazil, especially in the Amazon region. Even the remote possibility of an interventional by ecological motive was a serious threat for the military (Caninas, 2010).

The National Security Doctrine was no more in place and soon was replaced by a new political agenda (Lourenção, 2006) - the PCN or Programa Calha Norte, launched in 1985. Following a recommendation of Brazil's National Security Council, or Conselho de Segurança Nacional - (CSN,), a special interministerial Work Group was set up in 1985. Its objective: to draft a plan for economic development and enhancement of national security in the lands lying "north of the troughs (calhas) of the Solimões and Amazonas river'. According to Xavier de Sartre, the link between Amazon integration and national security was captured by slogans of the Integration National Program (Plano de Integração Nacional), which was launched by the 'hard line' military leadership of Emilio Garrastazu Médici. The motto was: 'integrate to not forfeit' or 'to give a land without men for men without land' (De Sartre; Taravella, 2009). The link between NGOs and the State related to them, and sometimes purely by nation ori- 
gins. The Armed Forces and specially the Brazilian Army was very suspicious about the foreign presence in the Amazon, which could be a sign of weakness, even if there was no evidence of such allegations. There were also geopolitical issues that appear during this period like the presence of the United States in Colombia (Teche, 2010) and the presence of drug lords in the borderlands (Rodrigues, 2001; 2002). Finally, the institutional issue regarding the organization of the $\mathrm{PCN}$ was considered an asset for developing a not-so-new policy. Although the Brazilian State had made a series of efforts developing a good relationship towards his oldest enemy (Argentina), now the country was facing a global reorganization, and depending on a diplomacy that focused in integration at a regional level.

\section{THE LIMITS OF PRESENCE INTO THE MILITARY STRUCTURE AND GEOPOLITICAL CHANGES IN THE REGION (2000-2017)}

Nowadays, it seems that Brazilian Armed Forces are investing in massive multi-million dollars projects in order to prepare its forces to the security challenges of the next century. Modernization of the Navy, creating a brand new national submarine fleet (known as Prosub) is one of the most ambitious public funding program ever developed in the nation. The strategic areas develop in the NDS document (nuclear, cybernetic and space) are contemplated by the FX-2 projects (for space dominance) but also the Brazilian Space Agency (BSA) providing a national satellite system integrating the Sisfron project (Dhenin, 2013). Needless to say that the modernization of the military is also an important investment regarding the industrial complex of Defense contractors in Brazil. Many big contracts were signed in order to guarantee the kickoff of those important programs. At the end of his second term, Lula left a new country, very active diplomatically, strong economically and increasing its partnership with strategic allies such as France (in 2008) or Russia (Muxagato, 2010). The conclusion of the contract between Brazil and Sweden in the purchase of 36 Gripen aircraft and also a milestone in the process of technology transfer between these countries. Those contracts had improved the leadership of Brazil regarding military affairs. However, the lack of regional preoccupation, namely with Argentina or Colombia, could also be an issue in a near future. The geopolitical context of Latin America is relatively quiet compared to other areas in the World (i.e. Middle East or Africa), but there are still many unsolved political issues between Peru and Colombia, the strange coup in Paraguay and the possible economic crisis in Argentina and the current crises in Venezuela 
According to the Constitution, Brazilian Armed Forces are in place to preserve the integrity of the Brazilian territory. However, the scenario has changed, and we use conventional forces in an unconventional context. The creation of a new civilian structure within the Brazilian government showed an important effort of normalization of the state. The approximation of the civil and military was a remarkable effort orchestrated by former president Fernando Henrique Cardoso during his campaign. According to Eliezer Oliveira (2005), the objective of the maneuver was a pragmatism element (reducing the cost of three Ministers into just one) and symbolic (the new ministry will be a symbol of democratization), with a civilian at the leadership. Another important element to stress the importance of civilian leadership was the creation in 2010 of the Estado-Maior Conjunto das Forças Armadas (or Joint Chief of Staff of Armed Forces) as a specialized structure to give a space for technical issues and give a quick answer (assess the President during turmoil). During the next decade, the domestic issues (financial and economic crises from 1990 to 2001 did not help to consolidate the Ministry of Defense. The severe budget cuts deeply affected the military capacity of Brazil and could not carry the modernization of strategic sectors such as the nuclear program for example.

Because of the difficult past and history between academics and military officers, the gathering of both sectors was a work put in place by FHC's successor, Luiz Inácio Lula da Silva. The leftist president took seriously the role of Brazilian Armed Forces, granting police power to the Brazilian Army in borderlands, through the Supplementary Law No. 97, of June $9^{\text {th }}$, 1999, as amended by Complementary Law No. 117 of September 2nd, 2004. From a legislative perspective, Lula also signed the Brazilian Shoot-Down Law (or Lei do Abate) during his first mandate. (Feitosa; Pinheiro, 2012). He launched the Pró-Defesa program that gave an actual structure and funds to develop research programs (for civil and military personnel), maintaining a special relationship with the military commands. Although the creation of the Ministry of Defense helped the integration of Armed Forces into a civil government, we can be more skeptical about the inputs that civilian personnel (like researchers) really offer and their influence on the decision-making process of the MD. Other initiatives were highlighted in this civil-military relationship during this period: the National Defense Academic Congresses (CADN) in the last 15 years, the national defense extension courses that take place throughout Brazil, among other actions promoted by the Ministry of Defense. It is also worth mentioning the creation of the Brazilian Association of Defense Studies (Abed) in 2005 by researchers and scholars in the area. 
The dialogue is positive in a way that it tries to reconciliate two former opposed groups, but there is a lot of space, and still a lot of possibility of influencing the strategic thinking of the Ministry of Defense. The NDS is an attempt to reduce the ideological gap between distinct institutions that are still lacking confidence in each other. This is a real issue, if compared to other countries. The emptiness of the Amazon region was always a sign of weakness for the Brazilian Army. However, recent social science studies reveal that the militarization of borderlands is not the only efficient solution for the Amazonia complex. Statistics gathered by the Brazilian Department of Justice during the last decade show that despite the common sense, those vast empty areas are in fact very dynamic and growing faster than the rest of the country.

If we look closely to the new threats gathered by the Retis program, we can see that there is a large number of transnational crimes that are committed and sometimes exclusively on the border. The Amazon region, and especially the Northern Arc part is part of the IIRSA program (Integration Initiative for Regionalization of South America). By creating big projects, and axis of development, it helped creating core of populations that were not there before and make it easy to go from a country to another one. Thus, increasing the trafficking in the most diverse areas of the enormous border (Machado, 2011).

We also emphasize that in the formulation of the IIRSA in $2000 \mathrm{It}$ sought to contemplate the economic, social, political and environmental aspects. Among the ten integration axes that make up the IIRSA, four are in the Amazon region. These are notable for their location in a region of great environmental and social vulnerability and potential for development. Transport and energy infrastructure are two of the pillars of the projects developed in the region and both have great potential for multidimensional impacts - environmental, social and economic. These impacts are felt by many communities that articulate - locally, nationally and regionally - in the search for a reorientation or paralysis of the projects developed.

Integration processes generally establish better security conditions in a region (Flores Jr.,. 2010). However, the equation of the integration / security binomial may not necessarily take place so that the first element strengthens the second. Integration projects are built multilaterally and, generally speaking, from top-level decisions and do not necessarily go through the scrutiny of the populations affected by them. This means that a process of integration built between different political units (States) may come across different perceptions of state security and still be faced with diverse interests of local groups directly impacted by integration proj- 
ects. This situation has been present in the last years in the transnational Amazon, that is, integrating projects directly influenced on security issues, evidencing the problematic articulation between the binomial regionalization and security.

The conflicts generated by the existing projects in the Amazon region have brought local, national and regional repercussions that can undermine / weaken a regionalization of cohesion among the Amazonian countries, which would have consequences for the South American integration (Correa, 2014).

Militarization is clearly incompatible with the dynamics and transformations that are happening in a large scale, in all borderlands. During several decades, starting with the Brasilia declaration of 2000, the integration was at the core of a liberal view of what should be the relationship between the countries: a big and diversified market, with production zones interconnected to big concentrated urban megalopolis. The so-called regionalization process also changed the scale of South America as an emerging global partner of U.S., the European Union and China. The Unasul initiative was settle in 2008 in order to offer a reliable structure to strengthen the dialogue inside the continent. One good example of the regional effort towards security and defense was the creation of the South American Defense Council (or Conselho Sul-Americano de Defesa) in order to harmonize the public policies of the Unasul ${ }^{2}$ members regarding the Defense sector. To go further, we can pay attention to Brazil's National Defense Policy (PND) that was adopted by decree on June $30^{\text {th }}$, 2005 (Saint-Pierre; Palacios Junior, 2014).

It states that 'the Brazilian Amazon, with its great mineral wealth and biodiversity potential, is the focus of intense international attention' (Saint-Pierre; Palacios Junior 2014, 8) and that given the strategic importance and the wealth it possesses, the Brazilian Amazon and the South Atlantic are priority zones for national defense. To counter the threats that weigh on the Amazon, it is essential to carry out a series of strategic activities geared to reinforcing military presence, to 'effective state action in socio-economic development and to an increase in cooperation with neighboring countries, with the aim of defending Brazil's natural wealth and natural environment' (Brazil, 2005). With the launch of the National Defense Strategy (Estratégia Nacional de Defesa in Portuguese) in 2008, the Ministry of Defense considered some sectors as a strategic priority (due to delay of technological and institutional nature) such as space, cyber and nuclear. The Amazon region is part of the key sectors for the development of the END. The guideline number 10, entitled - Prioritize the Amazon region - leaves no doubt about its importance for the defense of the coun- 
try. Quoting the text: 'The Amazon is one of the focuses of most interest to the defense. The defense of the Amazon requires advance sustainable development project and go through the triad monitoring / control, mobility and presence' (Brazil, 2012). The official document continues saying that 'Brazil will be vigilant in unconditional reaffirmation of its sovereignty over the Brazilian Amazon. Repudiating the practice of development actions and defense, any attempt to guardianship over their decisions regarding the development and preservation of the Amazon defense. We do not allow organizations or individuals serve as instruments for foreign interests - political or economic - that want to weaken the Brazilian sovereignty. Who takes care of the Brazilian Amazon, for the service of humanity and itself, is Brazil' (Brazil, 2012).

For decades, the Brazilian Armed Forces took almost full responsibility for the security component in the borderlands. From a strategic viewpoint, this position was very effective in order to guarantee its presence into the political debate. However, the actual situation is far different from the early 1980's, but the rhetorical argument kept the same: without a strong military presence in the borderlands, the State's authority will be in jeopardy. The Enafron initiative, launched by the Brazilian Department of Justice (Ministério da Justiça) in 2011 challenges that argument, investing hundreds of millions of brazilian reais to upgrade both civil and military security forces (state and local polices). The program also helped the Brazilian federal agencies (Federal Police, Federal Highway Patrol, IRS, etc.) to modernize its equipment's and prepare all borderlands personnel for specific tactical operations against illegal trafficking activities. To sum up, the Brazilian Armed Forces are now "encouraged" to cooperate with civilian security forces in order to keep its traditional narrative in place, in a moment of high political domestic instability since 2013.

\section{FINAL THOUGHTS}

As we can see, the path to a modern strategy regarding Brazil's border is far from being over. The quick historical viewpoints stressed in this paper evidenced that the actual situation of borderlands is in fact very complex. The difficulties are everywhere: the isolation of the borders with the municipalities and the federal services, the vulnerability of a growing population, the huge development differences with the rest of Brazil and the significant increase in illegal trafficking make borderlands a strategic area that must be a top priority for the federal government. However, the future of the northern border is very uncertain. As we presented, there was a lot of efforts that have been realized since the first Lula election in 
2003. Furthermore, we argue a certain continuity during the Rousseff's administration (government), that suffered in 2016 a very questionable process of impeachment. Recently, the manifested desire of increasing the presence of the military in the region, with the Protected Amazonia program, was simply put off the table by severe budget cuts. Although the military presence is important, mostly for the populations located in remote areas, the region still lacks of structural and logistical support for military and defense activities. Investments are still important but in a limited budget scenario, the flow of cash is going to be reduced rapidly, according to the institutional demand for efficient long-term investments. Of course, the size of the region requests to put these issues in perspective, because of its atypical proportions. However, Brazil needs to treat the region as a national problem, and not exclusively a security issue. However, in this scenario, a change is possible: the militarization of the region, echoing the securitization of the Amazonia, especially in the most isolated parts. As we know, the military presence is not necessarily the guarantee of a long-term development of these territories. The strategic challenge is clear: the federal government and the civil society as a whole need to normalize their relations, not only for the benefit of the populations, but also to change the Amazonian development. The liability of the region in this regard should be the subject of a national debate and seek all relevant authorities for even more accelerate the growth of Amazonia. All sectors, civil and military, would benefit from creating a new partnership, increasingly debating through annual meetings, both at the national and international level. A civil career (as Defense analyst) into the Brazilian Department of Defense represents an old process, that would clearly be a step forward into the construction and operationalization of specific strategies for Amazonia. Entering the $21^{\text {th }}$ century, the Amazonia population urges that its policymakers offer a clear signal of commitment with its border security, for itself and maybe the rest of the neighboring countries.

\section{BIBLIOGRAPHY}

Antiquera, D. C. 2008. A Importância do Tratado de Cooperação Amazônica para a Política Externa Brasileira (1995-2002). Cena Internacional, 10, 139-159.

Backheuser, E. 1952. Geopolítica Geral e do Brasil. Rio de Janeiro: Biblioteca do Exército.

Bueno, C. 2012. O Barão do Rio Branco no Itamaraty (1902-1912). Revista Brasileira de Política Internacional, Brasília, 55, 2, 170-189. 
Brazil. 2005. PDN, Plano de Defesa Nacional, Decreto 5484. Brasília: Imprensa Oficial.

Brazil. 2012. Estratégia Nacional de Defesa. Ministério da Defesa, Brasília: Imprensa Oficial.

Caninas, O. 2010. Intervenção Militar por Motivo Ecológico: Construção Teórica, Legitimidade e Possíveis Desdobramentos na Amazônia Brasileira. M. A. dissertation, Fluminense Federal University, Rio de Janeiro.

Correa, Paulo Gustavo Pellegrino. 2014. As Iniciativas de Integração e Segurança dos Países Amazónicos e o Papel do Brasil neste Contexto. Ph. D. diss., Universidade Federal de São Carlos, São Carlos.

Dos Santos, B. 2010. Os Jesuítas na Amazônia Portuguesa: a “Crise de vocações” e seus Reflexos na Missão do Maranhão e Grão-Pará. OPSIS, 9, 13, 100-118.

D’Araújo, M. C. 1992. Amazônia e Desenvolvimento à Luz das Políticas Governamentais: a Experiência dos Anos 50. Revista Brasileira de Ciências Sociais, 19,7 .

De Meira Mattos, C. 1990. Geopolítica e Território de Fronteiras do Brasil. Rio de Janeiro: Biblioteca do Exército.

De Sartre, X. A. ; Taravella, R. 2009. National Sovereignty vs. Sustainable Development Lessons from the Narrative on the Internationalization of the Brazilian Amazon. Political Geography, 09/28 (7), 406-415.

Dhenin, M. 2013. Do Sipam ao Sisfron: a Questão da Segurança da Faixa de Fronteira na Doutrina Militar Brasileira. In Nascimento, D. M. ; Rebelo Porto, J. L. (Org. ), Fronteiras em Perspectiva Comparada e Temas de Defesa e Segurança da Amazônia. Belém: Federal University of Pará.

Dreifuss, R. ; Dulci, O. 2008. As Forças Armadas e a Política. In Sorj, B. ; Almeida, M. (Org. ), Sociedade Política no Brasil pós-61. Rio de Janeiro: Centro Edelstein de Pesquisas Sociais. 132-181.

Evans, P. 1979. Dependent Development. Princeton: Princeton University Press.

Feitosa, G. R. P. ; Pinheiro, J. A. de O. 2012. Lei do Abate, Guerra às Drogas e Defesa Nacional. Revista Brasileira de Política Internacional, 55, 1, 66-92.

Ferreira, S. 2005. Federalismo, Economia Exportadora e Representação Política: o Amazonas na República Velha (1889-1914). Ph. D. diss, Campinas University, Campinas. 
Flores Jr., R. G. 2010. Blocos Regionais, Democracia e Conflitos In Kobim, N. A. ; Etchegoyen, S. W. ; Alsina, J. P. (Org. ), Segurança Internacional: Perspectivas Brasileiras. São Paulo, FGV editora. 141-150.

Gadelha, R. M. A. F. 2002. Conquista e Ocupação da Amazônia: a Fronteira Norte do Brasil. Estudos Avançados, 16, 45, 63-80.

Garfield, S. 2009. A Amazônia no Imaginário Norte-Americano em Tempo de Guerra. Revista Brasileira de História, 29, 57, 19-65.

Ginzburg, J. 2010. Euclides da Cunha, a Amazônia e a Barbárie. Estudos Avançados, 24, 69, 411-416.

Goldemberg, J. ; Durham, E. R. 1990. Amazonia and National Sovereignty. International Environmental Affairs, 2, 22-39.

Hall, A. L. 2000. Environment and Development in Brazilian Amazonia: from Protectionism to Productive Conservation. In Hall, A. (Ed. ), Amazonia at the Crossroads: The Challenge of Sustainable Development. London: Institute of Latin American Studies. 99-114.

Hepple, L. 1986. Geopolitics, Generals and the State in Brazil. Political Geography, 4, 79-90.

Kelly, P. ; Child, J. (Ed. ). 1988. Geopolitics of the Southern Cone and Antarctica. Boulder: Lynne Rienner.

Lourenção, H. J. 2006. O Sistema de Vigilância da Amazônia (Sivam): Velhas Controvérsias, Novos Desafios. In Castro, C. , Amazônia e Defesa Nacional. São Paulo: Fundação Getúlio Vargas.

Machado, L. O. 2011. A Estratégia Nacional de Defesa, a Geografia do Tráfico de Drogas Ilícitas e a Bacia Amazônica Sul-Americana. ECEME. Seminário de Defesa e Desenvolvimento Sustentável da Amazônia. Rio de Janeiro: ECEME. 99-113.

Mares, D. R. 2010. The National Security State. In Holloway, T. H. (Ed.), A Companion to Latin American History. Oxford: Wiley-Blackwell.

Marques, A. A. 2005. Amazônia: Presença e Pensamento Militar. Ph. D. diss, University of São Paulo, São Paulo.

Martins Filho, J. R. 2003. A Visão Militar sobre as "Novas Ameaças" no Cenário da Amazônia Brasileira. In: Soares, S. A. ; Mathias, S. K. (Org. ), Novas Ameaças: Dimensões e Perspectivas. São Paulo: Sicurezza. 
Muxagato, B. 2010. Le Rapprochement Franco-Bresilien: une Relation Strategique Au-Dela D’un Partenariat Militaire? Diplomatie. Les Grands Dossiers, 46, 25-32.

Oliveira, E. 1976. As Forças Armadas: Política e Ideologia no Brasil. Petrópolis: Vozes.

Oliveira, E. 2005. Democracia e Defesa Nacional: a criação do Ministério da Defesa na Presidência FHC. São Paulo: Ed. Manole.

Rodrigues, T. M. S. 2001. Política e drogas nas Américas. M. A. diss, Pontifícia Universidade Católica, São Paulo.

Rodrigues, T. M. S. 2002. A infindável guerra americana: Brasil, EUA e o narcotráfico no continente. São Paulo em Perspectiva, 16, 2, 102-111.

Saint-Pierre, H. L. ; Palacios Junior, A. M. C. 2014. The South American Defense Council (SDC) Confidence Measures: a Defense Expenditures Analysis (20092012). Revista Brasileira de Política Internacional, Brasília, 57, 1, 22-39.

Silva, G. 1967. Geopolítica do Brasil. Rio de Janeiro: Livraria José Olympio.

Stepan, A. 1971. The Military in Politics: Changing Patterns in Brazil. Princeton: Princeton University Press.

Stepan, A. 1973. The New Professionalism of Internal Warfare and Military Role Expansion. Yale University Press. 47-68.

Talbott, J. E. 1976. The Myth and the Reality of the Paratrooper in the Algerian War. Armed Forces and Society, 3, 1, 69-87.

Teche, C. H. 2010. As Transformações nas Forças Armadas Colombianas e os Reflexos para os Objetivos de Defesa do Brasil na Região Amazônica. M. A. diss, Fluminense Federal University, Rio de Janeiro. 


\section{NOTAS}

1. Bibliographical elements about Marshall Rondon's legacy in Amazonia can be found in the remarkable article in Dicionário Histórico Biográfico Brasileiro pós 1930. (2001) 2. ed. Rio de Janeiro: Ed. FGV.

2. In April 2018, Brazil, Argentina, Paraguay, Colombia, Chile and Peru sent a letter to the Unasur Pro-Tempore Presidency, informing the decision of their countries to suspend indefinitely participation in the bloc's meetings. Such a decision may represent the end of the block. 


\section{ABSTRACT}

This paper aims to offer a critical perspective regarding Brazil's border policies and its military presence. For decades, the Brazilian Armed Forces emphasized the 'Security and Development' doctrine as the solution to solve the many issues of the remote areas of the Amazon. In the late 1980's, even with the end of the Military Regime, such practices continued to dominate the agenda of policymakers. Nowadays, Brazil's young democracy faces new challenges regarding its 'brown areas', as O'Donnell theorized them. Our main goal here is to stress the lack of a critical thinking in the process of transformation of the regional reality. We evaluated the situation according to recent data gathered during several field trips in the Amazon region. The absence of a government presence, often pointed out as a strategic weakness by the military authorities, neglect the presence of various actors (population, NGOs, for example) committed to security. We argue that it is essential for the military to cooperate more with civilians, instead of militarizing the borders, to guarantee a safe presence for the population, and not only the security of a territory.

Keywords: Brazilian Armed Forces; Borderlands; Amazonia.

\section{RESUMO}

Este artigo apresenta uma perspectiva crítica sobre a presença militar e as políticas de fronteira no Brasil. Durante décadas, as Forças Armadas brasileiras introduziram a doutrina "Segurança e Desenvolvimento" como a solução para resolver os problemas nas áreas remotas da Amazônia. No final dos anos oitenta, apesar do fim do regime militar, tais práticas continuaram a dominar a agenda dos atores políticos. Hoje, a jovem democracia brasileira enfrenta novos desafios em relação às suas "áreas marrons" como Guillermo O'Donnell as teorizou. Nosso principal objetivo aqui é destacar a falta de pensamento crítico no processo de transformação da realidade regional. Nós avaliamos a situação de acordo com dados recentes recolhidos durante várias visitas de campo na região amazônica. A ausência de uma presença do governo tem sido muitas vezes apontada como uma fraqueza estratégica por parte das autoridades militares, ignorando a presença de diferentes atores (a população, as ONGs, por exemplo) comprometidos com a segurança fronteiriça. Argumentamos que é essencial para 
os militares o aumento da cooperação com os civis, em vez de acentuar a militarização das fronteiras, para garantir uma presença segura para as populações, e não apenas garantir a segurança do território.

Palavras-chave: Forças armadas brasileiras; Fronteiras; Amazônia. 